УДК 353.07:005.412

DOI: 10.34132/pard2019.04.11

\title{
ДЕРЖАВНЕ УПРАВЛІННЯ РЕГІОНАЛЬНИМ РОЗВИТКОМ НА ЗАСАДАХ ЄВРОПЕЙСЬКИХ СТАНДАРТІВ
}

Сиченко В.В., д-р наук $з$ держ., упр., професор, КЗВО «Дніпровська академія неперервної освіти», Дніпро, Україна

Мареніченко В.В., канд. наук 3 держ. упр, ст. викладач, Дніпровський державний аграрно-економічний університет, м. Дніпро, Україна

Визначено сутність розвитку регіонів в сучасній науковій літературі. Проаналізовано європейський досвід управління регіональним розвитком та базові принщипи здійснення регіональної політики СС. Визначено кониептуальні засади Державної стратегії регіонального розвитку на період до трьох років, засновані на європейських стандартах. Наголошено щэо регіональний розвиток дочільно трактувати як розвиток сочіально-економічної територіальної системи у просторовому аспекті, щуо поряд з просторовим розвитком иілісної системи також включає комплексний розвиток ї̈ соціально-економічних територіальних підсистем. Відповідно до цьього, регіональне управління має розглядатися як управління просторовим розвитком світу, наднаціональних територіальних формувань, держави або регіонів субнаціонального рівня як иілісними соціально-економічними комплексами та їх підсистемами. Акцентовано увагу на те щзо регіональне управління, щзо здійснюється у державі, являє собою діалектичне поєднання державного регіонального управління та самоврядування кожного з регіонів крайни. У свою чергу державне регіональне управління включає державне управління цілісним соціальноекономічним територіальним комплексом держави у просторовому аспекті та державне управління кожним регіоном країни як окремою підсистемою. 
В результаті проведених досліджень обгрунтовано застосування ефективних механізмів державного управління регіональним розвитком на засадах європейських стандартів в Украӥні.

Ключові слова: державне управління, регіон, розвиток, європейський стандарт

Постановка проблеми у загальному вигляді. Сучасний етап розвитку нашої держави знаменується потребою дієвих механізмів регіональної політики. Здійснення державного управління регіональним розвитком, заснованого на євростандартах та європрактиці, є основою швидкості та якості впровадження реформування як на конкретних територіях, так і в країні, загалом. Вирішення задач регіонального розвитку, вдосконалення владних відносин залежить, в першу чергу, від ефективного розподілу функцій управління та від правового та інституційного забезпечення розробки та впровадження регіональної політики держави.

Аналіз останніх досліджень та публікацій. Питанням регіонального розвитку, державному управлінню, європейським практикам регіональної політики присвячено наукові праці таких вчених, як: В. Вакуленко, Н. Васюткіна, О. Гордєєв, І. Грищенко, Д. Задихайло, Л. Ковальська, В. Куйбіда, М. Пітцик, Л. Ткачук, Й. Шумпетер та інших. Та слід зазначити, що сучасний рух нашої держави в СС вимірюється у геометричній прогресії, що обгрунтовує новий спектр для досліджень. Науковий та практичний досвід проведення регіональної політики, здійснення регіонального управління для регіонального розвитку $\mathrm{CC}$, а також відповідна нормативно-правова база стали предметом постійної дискусії. Український курс євроінтеграції потребує переосмислення в розробці і реалізації регіональної політики, яка має грунтуватися на вивченні, аналізі та використанні досвіду регіонального управління країн $Є С$, де є чудові приклади найоптимальнішого шляху подолання економічних протиріч та проблем.

Формулювання цілей статті (постановка завдання). Метою статті є обгрунтування застосування ефективних механізмів державного управління регіональним розвитком на засадах європейських стандартів. В рамках зазначеної мети поставлено наступні завдання: 
- визначити сутність розвитку регіонів в сучасній науковій літературі;

- проаналізувати європейський досвід управління регіональним розвитком, базові принципи здійснення регіональної політики СС;

- визначити концептуальні засади Державної стратегії регіонального розвитку на період до трьох років, засновані на європейських стандартах.

Виклад основного матеріалу дослідження. Згідно з Й. Шумпетером, під розвитком розуміються «такі зміни господарського кругообігу, які економіка сама породжує, тобто тільки випадкові зміни, покинуті напризволяще, і не проводяться в дію імпульсами середовища ззовні» [24].

В. Данилов-Дапільян стверджує, що скільки б не претендували на нього економісти, соціологи, культурологи та фахівці різних інших областей, розвиток має і походження, і зміст переважно екологічний» [8].

У зарубіжній економічній літературі проблему розвитку пов'язують, як правило, з управлінням капіталом, у тому числі природним [1].

Найпоширеніше визначення розвитку - це визначення, що представлено у доповіді «Наше спільне майбутнє» в Міжнародній комісії з навколишнього середовища та розвитку ООН у 1987 році: «сталий розвиток - це такий розвиток, що задовольняє покоління теперішнього часу, але не ставить під загрозу здатність майбутніх поколінь задовольняти свої власні потреби» [10].

В. Кухар визначив, що «сталий розвиток - це розвиток, що самопідтримується, це ідеологія розумної й обгрунтованої діяльності людини, яка живе у злагоді з природою та створює умови для кращого життя собі і наступним поколінням» [12].

На думку Л. Гринів, «розвиток - це забезпечення стабільного функціонування еколого-економічної системи через реалізацію ноосферної концепції» [6].

Є. Хлобистов зазначає, що «розвиток - методологічний орієнтир, який узгоджено $з$ національною ситуацією, особливостями національного соціально-економічного зростання, ментальністю» [20]. 
За 3. Герасимчук «розвиток - це процес забезпечення функціонування територіальної системи із заданими параметрами в певних умовах, протягом необхідного проміжку часу, що веде до гармонізації факторів виробництва та підвищення якості життя сучасних і наступних поколінь за умови збереження і поетапного відтворення цілісності навколишнього середовища» [4].

В. Лось зазначає, що розвиток пов'язаний з економічним зростанням, яке забезпечує задоволення матеріальних і духовних потреб теперішніх і майбутніх поколінь при збереженні рівноваги історично сформованих екосистем [16].

Слід погодитись 3 дослідженнями О. Шубравської, яка зазначила, що «сталий розвиток - це узгоджений розвиток економічних і соціальних процесів, а також навколишнього природного середовища» [23].

О. Латишева тримається думки, що розвиток пов'язано 3 досягненням економічної безпеки з урахуванням соціальної та екологічної складових потенціалу, збалансування яких досягається за допомогою системи ефективного управління та регулювання на різних ієрархічних рівнях [15].

Пов'язуючи реформу децентралізації влади із рівнем конкурентоспроможності територіальної громади, М. Пітцик зазначив, що «реалізувати соціальні, економічні та екологічні аспекти сталого розвитку, і тим самим, покращити якість життя населення можливо за умови концентрації влади на базовому рівні. Тобто, коли органи місцевого самоврядування мають можливість витрачати значні бюджетні кошти конкретного села, селища, міста на розвиток інфраструктури та сфери послуг за принципом субсидіарності; а також фінансувати наукові проекти та розробки науковців і фахівців 3 конкретних напрямів, в т. ч. спільних 3 міжнародними організаціями й установами, які в майбутньому компенсують ці втрати позитивним ефектом» [17].

У дослідженнях О. Гордєєва визначено, що «подальші перспективи наукових розробок стосовно державного регулювання сталого розвитку територіальних громад полягають у вдосконаленні підходів до реалізації механізмів забезпечення, визначенні принципів, 
індикаторів і показників оцінювання ефективності запровадження стратегічного партнерства в країні» [5].

Завдяки системному державному впливу є можливість забезпечення розвитку регіонів. Цей вплив має здійснювати система державного управління. Державне управління регіональним розвитком грунтується на цілеспрямованому систематичному впливі держави, який направлено на забезпечення збалансованого, соціально-орієнтованого регіонального розвитку для формування умов створення максимально рівних та високих соціальних стандартів, в не залежності від місця проживання на території держави [3].

Європейська практика регіонального розвитку має політичний принцип, згідно з яким багатші регіони забезпечують солідарність щодо бідніших регіонів, а також економічний принцип, згідно 3 яким низькі обсяги виробництва та низький рівень життя бідніших регіонів вважаються втратою потенціальних можливостей СС [19].

Сучасна політика розвитку регіонів $Є С$ включає три головні напрями:

- сприяння економічному наближенню (допомога менш розвиненим регіонам, зменшення відставання від розвинених регіонів);

- реалізація заходів, спрямованих на покращення конкурентоспроможності і зайнятості в регіонах;

- активізація співпраці та комунікацій між регіонами та країнами (зменшення економічного значення національних кордонів) [22]. Досвід регіональної політики СС за останні 20 років дозволив виділити ключові аспекти розвитку регіонів, серед яких слід виділити:

- вимоги стратегічного плану розвитку (виділення довгострокових цілей та векторів регіональної політики);

- можливості існування об'єктивних, «неполітичних» методів залучення та розподілу ресурсного потенціалу;

- систему об'єднання спільного фінансування;

- підтримку інтегрованих програм (інфраструктура, людський потенціал, розвиток бізнесу);

- варіативність грантової допомоги;

- проведення моніторингової діяльності регіонального розвитку 3 постійною демонстрацією у різноманітних формах звітності; 
- повагу до відкритих ринків СС (конкурентне середовище, відкритість державних закупівель);

- застосування правил екологічної політики;

- застосування принципів демократії та партнерства (запровадження фінансових санкцій за невиконання означених принципів) [11].

Враховуючи факт виконання більшістю країн всіх вимог регіонального розвитку $Є С$, все ж таки існують певні диспропорції у рівні життя та економічного розвитку, які з кожним етапом розширення тільки поглиблюються. Останнє розширення ЄС свідчить про збільшення на 10 \% об'ємів виробництва, на $22 \%$ - кількості населення, на 57 \% - кількості зайнятих у сільському господарстві, 30 \% - кількості безробітних. Населення, яке проживало в регіонах, в яких ВВП на душу населення менше, ніж третина середнього по ЄС показника, мало тенденцію росту до 62 мільйонів (3 24) (20\% населення). Обсяг ВВП на душу населення відрізняється від $28 \%$ від середнього по ЄС до $343 \%$ [25].

Слід зазначити, що найбільші обсяги фінансування в регіональній політиці $Є С$ призначені для найменш розвинених регіонів - 3 ВВП на душу населення нижче за 75\% (показник від середнього рівня (C). Такі регіони розташовані в більшій мірі серед країн Південної та Східної Свропи [26].

Результати досліджень показали, що в найближчій перспективі проблемні регіони Південної та Східної Європи будуть мати та демонструвати зростання ВВП на душу населення. Тим не менш, $\epsilon$ потенційні загрози загострення міжрегіональних відмінностей всередині країни, зростання диспропорцій серед великих міських агломерацій та економічної периферії.

Таким чином, є складнощі регіонального розвитку економічно слабких регіонів. Це, в свою чергу, зосередило сили СС на проведенні регіональної політики щодо наближення.

Для обгрунтування застосування ефективних механізмів державного управління регіональним розвитком на засадах європейських стандартів важливим є досвід формування регіональної політики $€ \mathrm{C}$. 
Серед основних цілей регіональної політики СС слід виділити:

- створення та забезпечення соціального, економічного, організаційного та правового поля;

- регіональний соціально-економічний розвиток з вирівнюванням диспропорційності;

- пріоритетність розвитку регіонів, які стратегічно $є$ важливими як для окремої країни, так і для всього СС;

- забезпечення максимального використання особливостей регіонів (природно-ресурсний потенціал);

- забезпечення комплексного екологічного захисту регіонів.

Слід докладніше проаналізувати зарубіжний досвід державного управління регіональним розвитком на прикладі країн ЄС. Єдина політика $\mathrm{CC}$ обгрунтовує наявність спільних для всіх країн принципів та підходів по відношенню до розвитку регіонів. Враховуючи застосування особливостей розвитку кожної із країн $Є C$, фактична реалізація базових принципів має виконуватися завдяки компетенції урядів країни. Принципи є базовими, але в рамках них регіональна політика може різнитися в залежності від використання внутрішнього потенціалу регіонів [7].

Наприклад, угорський уряд в регіональному розвитку вбачає реформування регіональної політики з пошуком внутрішнього потенціалу щодо розвитку сільських територій [13].

Серед регіональних особливостей розвитку Польщі слід виділити наступний пріоритет - моніторингова діяльність щодо визначення рівня регіонального розвитку та створення нових робочих місць $з$ одночасною підтримкою підвищення рівня конкурентоспроможності окремих регіонів 3 просуванням технологій та розвитком транскордонної комунікації.

В останні роки регіональна політика Польщі стала прикладом застосування європейських стандартів розвитку регіонів. Регіональна політика цієї країни грунтується на недопущенні деградації проблемних регіонів через забезпечення кожного громадянина гарантованими соціальними стандартами. Уряд Польщі активно стимулює економічне зростання регіонів 3 провідними позиціями у забезпеченні значної частки національного доходу. Фінансування 
передбачається в більшій мірі для розбудови інфраструктури, розвитку бізнесу та підвищення рівня життя громадян. Значну увагу уряд Польщі приділяє підвищенню кваліфікації.

Досвід Польщі у регіональній політиці засвідчує факт високої ефективності запровадження європейських стандартів та є гарним прикладом для України. Українському уряду слід звернути увагу на практичний досвід Польщі в управлінні регіональним розвитком. Доцільним є перспективна оцінка політики регіонального розвитку у процесах підготовки до вступу в СС з аналізом невирішених питань польської влади.

А втім, не тільки Польща має практичні аспекти застосування європейської практики регіонального розвитку. В Естонії регіональна політика будується через Міністерство внутрішніх справ, оскільки одне із головних завдань політики держави - збереження територіальної цілісності. Завдання регіональної політики Естонії виходять із головної мети - створення сприятливих умов життя зі стимулюванням оптимального економічного розвитку регіонів.

Румунія значним чином відстає від попередніх країн в економічному розвитку, але швидко набирає темпи проведення інституалізації регіональної політики. Її концепцію в регіональній політиці уряд розробляє при залученні експертів Сврокомісії.

У Фінляндії відповідальним за формування регіональної політики є Міністерство внутрішніх справ. Процес розвитку регіонів забезпечується координацією діяльності центральних міністерств різних напрямів. Основні рішення у соціально-економічному регіональному розвитку приймають централізовано, а регіони мають право приймати окремі рішення в результаті застосування попередньо розроблених проектів. Країни Північної Свропи мають суттєвий досвід у проведенні регіональної політики з централізованим підходом (Франція, Нідерланди, Австрія, Бельгія).

У ракурсі сучасного процесу впровадження реформ в Україні, актуальним є досвід Франції в об’єднанні муніципалітетів. Тридцять років тому уряд Франції спробував розпочати примусову реформу територій, яка була спрямована на злиття муніципалітетів, що були створені за часів Французької революції. Слід відмітити відхилення насе- 
ленням примусового злиття. Таким чином, відбулася трансформація означеного процесу у процес створення міжкомунальних об'єднань, що взяли на себе практично всі питання у державному фінансуванні (інвестуванні та поточних витратах) на місцевих рівнях [2].

Зовнішньополітична діяльність уряду Хорватії суттєво пов'язана 3 комплексною програмою впровадження внутрішнього реформування, що забезпечує реорганізацію державної влади, економічний розвиток та повноцінне впровадження європейських демократичних стандартів, серед яких гарантії безпеки громадянських та релігійних свобод, верховенство права, рівноправність громадян та право кожної окремої людини на однакові життєві умови.

Обгрунтування застосування ефективних механізмів державного управління регіональним розвитком на засадах європейських стандартів грунтується на базових принципах регіональної політики $\mathrm{CC}$, серед яких слід виділити:

1. Субсидіарність (громадсько-політичний принцип, за яким органи влади вищого рівня мають право і повинні розв'язувати лише ті проблеми, на виконання яких органи влади нижчого рівня не спроможні. На практиці це означає, що планування, складання програм, виконання та управління підтримкою регіонального розвитку починається на регіональному й місцевому рівнях шляхом координації, досягнення консенсусу та процесу розстановки пріоритетів, результатом чого є багаторічний програмний документ національного рівня) [14].

2. Децентралізація (розширення повноважень місцевих органів виконавчої влади та органів місцевого самоврядування, а також перерозподіл бюджетних ресурсів, надання дотацій із спільного бюджету та фондів СС на користь менш розвинутих регіонів 3 метою досягнення певного вирівнювання диспропорцій у економічному розвитку різних регіонів та досягнення політичної стабільності. Це заохочує до створення регіональних ініціатив та вихід на траєкторію стійкого соціально-економічного росту);

3. Партнерство (можливість рівноправного співробітництва між суб'єктами різних рівнів: територіально-адміністративних 
одиниць, національних та місцевих органів влади, між державним і приватним сектором у визначенні, розробці та виконанні спільних завдань, програм і підпрограм щодо регіонального розвитку) [18].

4. Програмування (розробка на основі партнерства стратегії соціально-економічного розвитку, в якій програми на конкретних рівнях прийняття рішень максимально узгоджені з іншими програмами. Принцип партнерства у політиці ЄС обгрунтовує пріоритет інвестування не окремого проекту, а програми, яка має вплив на розвиток всього регіону);

5. Концентрація і адиціоналізм (реалізація даних принципів передбачає, що фінансові ресурси, що надаються СС, мають доповнюватися місцевими джерелами фінансування. Метою принципів $\epsilon$ пошук та розвиток власних джерел фінансування заходів 3 регіонального розвитку) [21].

Важливим моментом розвитку регіонів України є впровадження Державної стратегії регіонального розвитку на період до трьох років. Загалом, стратегія грунтується на деяких концептуальних засадах та відповідних їм заходах, зокрема виділено ті, які стосуються регіонального управління та розвитку, заснованих на європейських стандартах та євроінтеграції України:

1) підвищення рівня конкурентоспроможності регіонів:

- популяризація інвестиційного потенціалу України у світовому середовищі;

- стратегічне планування розвитку регіонів 3 урахуванням смарт-спеціалізацій (світові ринкові та технологічні тенденції інноваційного розвитку);

- врегулювання на законодавчій основі питань розробки та координації регіональної програми розвитку промисловості через використання механізмів державної підтримки пріоритетних сфер розвитку, визначених на смарт-спеціалізаціями;

- врегулювання на законодавчій основі питань інтеграції національної туристичної сфери в туристичний простір $\mathrm{CC}$;

2) територіальна соціально-економічна інтеграція і просторовий розвиток: 
- розробка нової Генеральної схеми планування територій України (інтерактивна моделююча система управління країною з визначенням стратегії просторового розвитку);

- визначення на регіональних та місцевих рівнях пріоритетів та завдань по формуванню, збереженню та невиснажливому використанню екомереж;

- визначення на регіональних та місцевих рівнях напрямів розвитку системи надання соціальних послуг, у тому числі, підтримки бізнесу;

- створення законодавчої бази для здійснення оптимального розподілу повноважень серед суб'єктів: органи виконавчої влади та органи місцевого самоврядування (принципи: субсидіарність та децентралізація) [9].

Головна проблема в регіональній політиці грунтується на недосконалій сформованості системи інститутів, які готові взаємодіяти та координувати здійснення ефективної реалізації завдань в регіональній стратегії суспільного розвитку. Окрема частина функцій по регулюванню розвитку регіонів розосереджена по різним інстанціям, які включають свої регіональні підрозділи. Таким чином, існує, в особливій мірі, складна та дуже важлива проблематика у координації діяльності неспеціалізованих органів влади та в їх зусиллях консолідувати власні дії в загальній системі загальнодержавної політики.

Слід детальніше розглянути зовнішні та внутрішні загальнодержавні перешкоди при реалізації стратегії регіонального управління та суспільного розвитку.

Зовнішні перешкоди визначаються:

- негативним впливом світових фінансових криз у кредитнобанківській сфері (уповільнення кредитної активності);

- згортанням (зменшенням) інвестиційного потоку та віддік коштів-депозитів у зв'язку із втратою довіри громадян до банківської системи;

- високою експортною залежністю економіки;

- погіршенням та уповільненням темпів росту виробництва;

- військовою ситуацією на сході держави. 
Внутрішні чинники визначаються:

- високим рівнем інфляційних процесів та підвищення відсоткової ставки за кредитом (результатом $є$ зниження темпу приросту в більшості секторів економіки);

- втратою податкового надходження у зв'язку зі значною кількістю збиткових підприємств або з нульовим прибутком (зростання загального податкового боргу, що призводить втрати та незабезпеченості фінансовим ресурсом, надходжень до бюджетної системи країни та скорочень фінансування;

- низькою інвестиційною привабливістю та можливістю розширення масштабу у залученні іноземних коштів;

- несприятливою ціновою політикою у сфері сільського господарства, ПММ;

- небезпечно низьким рівнем платоспроможності як бізнесу, так і населення, низькою можливістю заощаджувати;

- змінами в законодавстві, які унеможливлюють використання планових витрат коштів у запланованих розмірах;

- форс-мажорними обставинами, які мають природний зміст.

Характерна ознака сучасної України - це орієнтація європейської інтеграції. Таким чином, це висуває ряд завдань для нашої держави, пріоритетне значення серед яких мають:

- реформа владних відносин;

- визначення стратегій здійснення суспільного розвитку;

- дотримання збалансованих показників розвитку регіонів з підвищенням їхньої конкурентоспроможності.

3 практичної сторони цих завдань існує необхідність проведення удосконалень в національній системі регіонального управління, у реформуванні місцевого самоврядування та адміністративно-територіального устрою в інтересах територіальних громад.

Сучасні проблеми регіонального управління та розвитку, які набули особливої гостроти, грунтуються на:

- незбалансованості та посиленні диспропорцій соціально-економічного розвитку в регіонах; 
- невідповідності наявної в Україні системи адміністративнотериторіального устрою до сучасних умов управління та європейських вимог ефективності публічної влади.

Не до кінця визначеною є територіальна основа в місцевому самоврядуванні (громаді), що веде до неповноцінного здійснення формування ефективної публічної влади в нашій країні. Зазначена ситуація не дозволяє в повній мірі врахувати потреби населення, громадян відповідної територіальної одиниці, а також чинить перешкоди на шляху ефективного здійснення регіональної політики на рівні держави та на місцях.

Застарілі норми системи та базові принципи регіонального управління в Україні актуалізують проведення досліджень у даному напрямі. Основні мотиви реформування системи регіонального управління, удосконалення стратегій розвитку регіонів грунтуються на низці причин, а саме:

- на недосконалому нормативно-правовому забезпеченні регіонального управління;

- на відсутності принципів комплексності та системності у розробці впровадженні регіональної політики держави як цілому, так і стратегій та програм регіонального розвитку, зокрема;

- на надмірній централізації у питаннях управління регіонального розвитку із недостатнім врахуванням інтересу та особливості регіону в управлінні ним;

- на слабкості інститутів громадянського суспільства та низькому рівні територіальних громад у залученості їх у вирішення питань розвитку територій;

- на недоліках у фінансовому забезпеченні регіонального управління (недостатність фінансового ресурсу місцевого бюджету, високий рівень залежності від субвенцій держави, неготовність та невміння органів регіонального управління шукати альтернативні джерела фінансування для вирішення питань розвитку власної територіï).

Слід зазначити, що кризовий стан економіки нашої держави, який охарактеризований коливаннями валютного курсу, скороченням ринків збуту, падінням національної валюти, стрімким знижен- 
ням реальних доходів громадян призвів до погіршення стану в колосальній мірі більшості українських бізнес-структур.

У зв'язку з цим, виникають наслідки подальшого спаду економічної активності населення, а це показує й істотне ускладнення наявних проблем в регіональному управлінні. Сучасні умови розвитку як держави, так і окремих іiі територій, районів, потребують приділення першочергової уваги реалізації механізмів з мінімізації наслідків кризи для стабілізації економічної ситуації. Слід відмітити один із напрямів по забезпеченню подальшого розвитку економіки країни в умовах європейської інтеграції, а саме, підтримку курсу інноваційного розвитку економіки країни та регіональних територій.

Будь-яке управління в сучасному середовищі, буде це бізнес, країна або район, вимагає використання інноваційних підходів, враховуючи його відповідність вимогам часу. Впровадження інноваційного шляху регіонального розвитку слід зорієнтувати на:

- підвищення рівня мотивації до суспільного процвітання та зростання;

- створення на регіональних рівнях ефективно діючих господарських структур, які орієнтовані на інтенсифікацію місцевого ресурсного потенціалу;

- формування на регіональних рівнях конкурентних виробничих систем $з$ інноваційними характеристиками;

- першочергове задоволення внутрішньої потреби території.

Відомі європейські інноваційні підходи до регіонального управління переконують у їх ефективності через багатороковий термін ïх використання 3 показовими результатами ефективності. Тим не менш, через наявність перешкод у регіональному розвитку, подібні підходи не застосовуються, або застосовуються в незначній ролі. Серед таких підходів слід виділити:

- кластерний підхід (створення і розвиток кластерів в різних формах та секторах регіональної життєдіяльності. Кластерний підхід сприяє об'єднанню виробничого та наукового потенціалу регіону, поетапному досягненню стратегічної мети регіонального розвитку з виконанням поставлених завдань, покращанню показників 
соціально-економічного характеру та розбудові соціальної та виробничої регіональної інфраструктури);

- підхід державно-приватного партнерства (основна задача у створенні партнерства, яке забезпечує задоволення соціальних потреб громадян та розвиток соціальної інфраструктури);

- підхід міжрегіонального співробітництва (практика створення різного типу співробітництва між районами, регіонами, територіями в економічному, соціальному, культурному, освітньому та інших секторах. Крім підвищення потенціалу розвитку регіону та досягнення кращих соціальних та економічних результатів, така взаємодія налагоджує міжрегіональні зв'язки, що ускладнюються внаслідок суспільного процесу, що відбувається в нашій країні, та тривалій спекуляції політичної сили на регіональних відмінностях. Важливою базою європейської практики є міжрегіональне співробітництво з іншими країнами, що сприяє підвищенню рівня застосування внутрішнього потенціалу регіонів та темпів розвитку).

Впровадження інноваційного підходу регіонального управління висуває вимоги зміни розуміння процесу та сутності регіонального управління, тобто соціального фактору, а також законодавства згідно європейських стандартів, тобто організаційно-правового фактору. При цьому виникають деякі перешкоди неповноцінного розуміння даних практик зі сторони владних структур.

Для нівелювання зазначеної перешкоди слід застосувати принцип комплексності, що передбачає впровадження в регіональному управлінні наступних векторів та усунення проблем:

- накопичення інфраструктури з інноваційним напрямом в районах;

- застосування механізмів забезпечення корпоративної культури серез публічних службовців;

- використання творчого ресурсу;

- встановлення максимального рівня комунікацій між людиною та владною структурою;

- децентралізація в регіональному управлінні;

- використання пропагандистських механізмів роботи з громадськістю, які спрямовані на реалізацію змін у свідомості людей та прийнятті власної ролі в процесі розвитку регіону. 
В нашій країні протягом останніх років на рівні територіальних громад бачимо певний прогрес у самоврядуванні. А втім, слід відмітити, що цей процес характеризується принципами нерівномірності та суперечливості. Основна причина цього фактору пов'язана 3 недосконалістю сучасного законодавства, яке, на відміну від європейської практики, допускає невиправданість розподілу повноважень між державною владою та місцевим самоврядуванням в районах. Це веде до необхідності в негайній мірі застосування концептуальних засад реформації.

Сьогодні існує надзвичайно низька база статистичного супроводу регіонального управління та практично відсутня загальноохоплююча статистична інформація. Відповідно, існує потреба активної перебудови системи статистики як країни, так і окремих регіонів згідно положень нормативної документації ЄС у статистичному обліку, а також при застосуванні європейської уніфікованої статистичної методології в регіональному управлінні.

Важливою та актуальною перешкодою у регіональній політиці залишається низьке кадрове забезпечення. Важливим фактором успіху діяльності в регіональному управлінні є зміцнення потенціалу регіонів та ефективному його використанні, що забезпечується збільшенням кількості фахівців своєї справи та якістю професійної підготовки.

Надмірний політичний вплив має бюджетний процес, що означає формування планово-бюджетних перешкод. В ракурсі політичних баталій державний бюджет приймають невчасно, що призводить до запізненого формування бюджетів нижчих рівнів. Такі тенденції формують негативний імідж для припливу іноземного інвестування.

Таким чином, слід відмітити важливість розв'язання важливих проблем і задач, що являються перешкодами на шляху ефективної реалізації стратегії регіонального управління та розвитку.

Дослідження показали, що стратегію регіонального управління та суспільного розвитку слід направити у наступних векторах (підтримка та розвиток сильних сторін та перспективних можливостей): - європейські орієнтири населення у розвитку регіонів; 
- зміни стереотипу із «за все відповідає держава» на «я - результат власних дій»;

- підтримка малого та середнього бізнесу в регіонах;

- швидкий розвиток малого та середнього бізнесу завдяки впровадженню європейських стандартів регіонального управління та розвитку.

Головна мета регіонального європейського управління направлена на створення умов по стимулюванню економічної активності населення на регіональному рівні з наданням регіонам більшої свободи у сфері бізнес вибору з використанням ефективних інструментів та механізмів стимулювання малого та середнього бізнесу, місцевих економічних ініціатив та досягнення на цій базі збалансованості регіонального розвитку.

Враховуючи євровибір України, регіональне управління слід направити на використання та відповідність до європейських норм та стандартів.

Висновки. В сучасних умовах можливості соціально-економічного розвитку країни залежать від розвитку іiі окремих територій, а при цьому виникає ряд проблем та задач, зокрема, забезпечення регіонального розвитку та підвищення ефективності регіонального управління. Досягнення високого рівня ефективності та результативності в регіональному управлінні має грунтуватися на застосуванні ефективних механізмів державного управління регіональним розвитком на засадах європейських стандартів. В результаті проведених досліджень було визначено кращі європейські практики державного управління регіональним розвитком. Зокрема, враховано досвід Польщі, Естонії, Фінляндії, Румунії, Франції, Нідерландів, Австрії, Бельгії, Хорватії, Угорщини. Дослідження показали можливості використання регіональних особливостей розвитку зазначених країн. Якщо додати до підтримки ЄС особливості і можливості регіонів нашої країни, то Україна має всі шанси у впровадженні європейських практик регіональної політики з виходом на новий рівень регіонального розвитку.

\section{Стаття надійшла до редакціi: 21.02.2019}




\section{STATE MANAGEMENT OF REGIONAL DEVELOPMENT ON THE BASIS OF EUROPEAN STANDARDS}

Viktor Sychenko, Rector, Doctor of Sciences in Public Administration, Professor, CIHE "Dniprovska Academy of Continuing Education", Dnipro, Ukraine.

Valery Marenichenko, Senior Lecturer of the Department of Management, Public Administration and Administration, $\mathrm{PhD}$ in Public Administration, Dnipro State Agrarian and Economic University, Dnipro, Ukraine

The modern stage of development of our state is marked by the need for effective mechanisms of regional policy. The implementation of public management of regional development, centered around European standards and European practice, is the basis of the speed and quality of the implementation of reforms both in specific territories and in the country as a whole. The solution of the tasks of regional development, improvement of power relations depends, first of all, on the effective allocation of functions of management and on the legal and institutional support for the development and implementation of regional policy of the state.

The scientific and practical experience of conducting regional policy, the implementation of the regional management for EU regional development, as well as the relevant regulatory and legal framework have become the subject of ongoing discussion. The Ukrainian course of European integration needs to be rethought in the development and implementation of regional policy, which should be based on the study, analysis and use of the experience of regional management of the EU countries, where there are excellent examples of the most optimal way to overcome economic contradictions and problems.

The purpose of the article is to justify the use of effective mechanisms of state management for regional development on the basis of European standards. Within this objective:

- the essence of development of regions in modern scientific literature is determined. In particular, state management of regional development 
is based on the purposeful systematic influence of the state aimed at ensuring balanced, socially-oriented regional development in order to create conditions for the creation of the highest possible and equal social standards, regardless of the place of residence and the territory of the state;

- the European experience of regional development management and the basic principles of the implementation of the EU regional policy is analyzed. In particular, it is determined that the current policy of the development of the regions of the EU includes three main directions: promoting economic convergence (assistance to less developed regions, reducing the lagging behind of developed regions); implementation of measures aimed at improving competitiveness and employment in the regions; intensification of cooperation and communication between regions and countries (reduction of economic value of national borders). In addition to the general tendencies of the regional policy of the EU, key features of the regional development of individual countries are identified;

- the conceptual foundations of the State Strategy for Regional Development

for a period up to three years, based on European standards, are defined. An important moment in the development of the regions of Ukraine is the implementation of the State Strategy for Regional Development for a period up to three years. In general, the strategy is based on some conceptual foundations and their respective measures, in particular, those that are related to regional management and social development based on European standards and European integration of Ukraine, namely, regional competitiveness and territorial socioeconomic integration and spatial development are highlighted.

As a result of the conducted research, the use of effective mechanisms of state management of regional development based on the principles of European standards in Ukraine has been substantiated.

Thus, it should be noted that under the current conditions, the country's social and economic development opportunities depend on developing its separate territories, while a number of problems and tasks arise, in particular, ensuring regional development and improving the efficiency of regional management. Achieving a high level of efficiency 
in regional management should be based on the application of effective mechanisms of state management of regional development based on European standards.

As a result of the research, the best European practices of state management of regional development have been identified. In particular, the experience of Poland, Estonia, Finland, Romania, France, the Netherlands, Austria, Belgium, Croatia and Hungary has been taken into account. Studies have shown the possibility of using the regional peculiarities of the development of these countries. By adding to the EU'S support the features and capabilities of our country's regions, Ukraine has all chances to implement European regional policy practices with a new level of regional development.

Keywords: state management, region, development, European standard.

\section{Received: 21.02 .2019}

\section{References}

1. Blam Y.Y. (2000). Ustoychyvoe razvytye: osnovnye teoretycheskye problemy / Y.Y. Blam // Rehyon: ékonomyka i sotsyolohyya. - S. 103. [in Ukrainian]

2. Vakulenko V.M. (2014). Rehional'ne upravlinnya : pidruchnyk / za zah. red. V.M. Vakulenka, M.K. Orlatoho. - K. : NADU, 2014. - 516 s. [in Ukrainian]

3. Vasyutkina N.V. (2017). Stalyy rozvytok yak osnova zrostannya natsional'noyi ekonomiky: problemy, shlyakhy vyrishennya / N.V. Vasyutkina // Ekonomichnyy visnyk universytetu, K. 34(1)., - S. 150-163.

4. Herasymchuk Z.V. (2001). Rehional'na polityka staloho rozvytku: metodolohiya formuvannya, mekhanizmy realizatsiyi. Luts'k: Vyd-vo «Nadstyr'ya»,- 528 p. [in Ukrainian]

5. Hordyeyev O.K.(2014). Mekhanizmy zabezpechennya staloho rozvytku terytorial'noyi hromady: dys. ... kand. nauk z derzh. upr.: 25.00.04 / O.K. Hordyeyev; Nats. akad. derzh. upr. pry Prezydentovi Ukrayiny; Odes. rehion. in't derzh. upr. - Odesa, 2014. - 200 s. [in Ukrainian]

6. Hryniv L.S. (2001). Kontseptual'ni zasady prostorovoyi paradyhmy ekolohichno zbalansovanoyi ekonomiky / L.S. Hryniv // Rehional'na ekonomika. [in Ukrainian] 
7. Hryshchenko I.M. (2018). Zarubizhnyy dosvid upravlinnya rehional'nym rozvytkom / I.M. Hryshchenko - Retrieved from: http://www.dy.nayka.com.ua/ pdf/5_2018/5.pdf [in Ukrainian]

8. Danylov-Danyl'yan V.Y. (2003). Ustoychyvoe razvytye (teoretykometodolohycheskyy analyz) / V.Y. Danylov-Danyl'yan // Ékonomyka y matematycheskye metody. [in Ukrainian].

9. Deyaki pytannya realizatsiyi u 2018-2020 rokakh Derzhavnoyi stratehiyi rehional'noho rozvytku na period do 2020 roku - Rezhym dostupu: https:// zakon.rada.gov.ua/laws/show/733-2018-\%D0\%BF/print [in Ukrainian].

10. Dopovid' «Nashe spil'ne maybutnye» Mizhnarodnoyi komisiyi z navkolyshn'oho seredovyshcha ta rozvytku OON, 1987 r. -. Retrieved from: http://www.un.org/ documents/ga/res/42/ares42-187.htm. [in Ukrainian].

11. Zadykhaylo D.V. (2012). Hospodars'ko-pravove zabezpechennya ekonomichnoyi polityky derzhavy: monohrafiya / D.V. Zadykhaylo. - Kharkiv : Yurayt,- [in Ukrainian]

12. Kukhar V.P. Problemy Ukrayiny - perekhid do staloho rozvytku. / V.P. Kukhar - Retrieved from: http://www.medved.kiev.ua/ arhiv_mg/ stat_98/98_3_1.htm. [in Ukrainian]

13. Kuybida V.S. (2009). Rehional'nyy rozvytok ta prostorove planuvannya terytoriy: dosvid Ukrayiny ta inshykh derzhav-chleniv Rady Yevropy : zb. normat.-prav. aktiv i nauk.-analit. materialiv z pytan' rehional'noho rozvytku ta prostorovoho planuvannya / V. S. Kuybida, V. Nehoda. - K. : Vyd-vo "Kramar", - 176 s. [in Ukrainian].

14. Kuybida V. (2010). Rehional'na polityka: pravove rehulyuvannya. Svitovyy ta ukrayins'kyy dosvid / V. Kuybida, A. Tkachuk, T. Zabukovets'Kovachych; za zah. red. R. Tkachuka. - K. : Lesta, - 224 s. [in Ukrainian]

15. Latysheva O.V.(2006). Etapy upravlinnya ekolohichnoyu skladovoyu potentsialu staloho rozvytku mashynobudivnykh pidpryyemstv / O.V. Latysheva // Ekonomichnyy visnyk Donbasu. - 3 (45). - p. 126. [in Ukrainian]

16. Los' V.A. (2000). Ustoychyvoe razvytye: ucheb.posobye / V.A. Los' // Moskva: Ahar. - 253 s. [in Russian].

17. Pittsyk M. (2016). Detsentralizatsiyi mozhe zavadyty politychne seredovyshche, yake ne khoche zmin / M. Pittsyk - Retrieved from: http:// decentraliza' tion.gov.ua/news/2357 [in Ukrainian]

18. Rehional'nyy rozvytok $\mathrm{v}$ Yevropeys'komu Soyuzi: uroky dlya Ukrayiny. - Retrieved from: http://www.ssrd.org.ua/content/ukr/prjdoc/Best practices_UA.pdf. [in Ukrainian]. 
19. Tkachuk L.M. (2012). Orhanizatsiyno-pravovi aspekty derzhavnoho upravlinnya rehional'nym rozvytkom / L.M. Tkachuk, T.K. Kaluharyanu // Efektyvna ekonomika. - \#12. [in Ukrainian]

20. Khlobystov Y.V. (2004). Ekolohichna bezpeka transformatsiynoyi ekonomiky / Y.V. Khlobystov // K: Chornobyl'interinform. - p. 336. [in Ukrainian].

21. Sharmoyants A.N. (2012). Perspektyvy razvytyya rehyonalyzma v Evrope / A.N. Sharmoyants // Uchenye zapysky Tavrycheskoho natsyonal'noho unyversyteta ym. V.Y. Vernadskoho, Seryya "Yurydycheskye nauky», tom 25 (64). \# 2. - P. 107-110. [in Ukrainian].

22. Shkrabak I.V. (2010). Derzhavne upravlinnya i mistseve samovryaduvannya: symbioz orhanizatsiyi i samoorhanizatsiyi v terytorial'nomu upravlinni / I.V. Shkrabak // Menedzher. - - \#4 (46). - P. 55-62. [in Ukrainian].

23. Shubravs'ka O. (2005). Stalyy ekonomichnyy rozvytok: ponyattya i napryam doslidzhen' / O. Shubravs'ka // Ekonomika Ukrayiny. - \# 1. - P. 36. [in Ukrainian].

24. Shumpeter Y. (2007). Teoryya ékonomycheskoho razvytyya / Y. Shumpeter. - M. : Éksmo, - 864 p. [in Russian].

25. Eurostat Regional Yearbook 2014. - Luxembourg: Publications Office of the European Union, 2014. P. 120. - Retrieved from: http://ec.europa.eu/ regional_policy/index.cfm/en/policy/cooperation/european-territorial. [in English].

26. Regionalpolitik und Europa 2020. Retrieved from: http://ec.europa.eu/ eurostat/statistics-explained/index.php/Regional_policies_and_Europe_2020 [in English]. 


\section{Відомості про авторів / Information about the Authors}

Сиченко Віктор Володимирович: Комунальний заклад вищої освіти «Дніпровська академія неперервної освіти», вул. Антоновича, 70, м. Дніпро, 49006, Україна

Victor Sychenko: Communal Institution of Higher Education "Dnipro Academy of Continuing Education", st. Antonovich, 70, Dnipro, 49006, Ukraine

ORCID. ORG./ 0000-0001-9655-2317

E-mail: sychenko@dano.dp.ua

Мареніченко Валерій Валентинович: Дніпровський державний аграрно-економічний університет, вул. Єфремова, 25, м. Дніпро, 49600, Україна

Valery Marenichenko: Dnipro State Agrarian and Economic University, st. Efremova, 25, Dnipro, 49600, Ukraine

ORCID. ORG./ 0000-0002-0183-1354

E-mail: marenichenkov@gmail.com 